\title{
Al-Chizan
}

Jurnal Pemikiran Hukum Islam

ISSN 1907-0985, E ISSN 2442-8256

Vol. 14, No. 1, 2018, h. 1-18

DOI: https://doi.org/10.30603/am.v14i1.930

\section{Telaah Ayat-Ayat Hisab Rukyah Perspektif Astronomi}

\section{Nursodik}

Institut Agama Islam Negeri Sultan Amai Gorontalo

Email: nursodik@iaingorontalo.ac.id

Abstract: The discourse of the verses of the Qur'an regarding the reckoning (hisab) and determining date by sighting of moon (rukyat) did not find passages that describe implicitly on an initial determination by using the lunar month of reckoning, but explicitly there are several verses in the Qur'an that mention reckoning in relation to the existence position of the moon and sun. The correlation or relationship verses of the Koran to the concept of astronomy (reckoning rukyah) based on the interpretations and asbab al-nuzul show harmony with the science of astronomy. Therefore, the science of astronomy is needed as a tool for understanding the verses of Allah in the Qur'an and in the universe. Thus signaling a clear and complete information about the procedure of reckoning and rukyat preliminary determination of the Moon in the Qur'an now we'll get to bridge the bridge between the message of the Qur'an and as-Sunnah (proposition syari), rukyat or observation and reckoning is required a comprehensive understanding of the objective - scientific paradigm in understanding the concept of reckoning and rukyah as a single entity that can not be separated.

Keywords: Astronomy, Science, Observation, Moon

\section{Study of Verses of the Hisab Rukyah in Astronomical Perspective}

Abstrak: Diskursus ayat-ayat al-Quran yang berkenaan dengan hisab rukyat memang tidak ditemukan ayat-ayat yang menjelaskan secara implisit tentang penentuan awal Bulan Kamariah dengan menggunakan hisab, namun secara eksplisit ada beberapa ayat al-Qur'an yang menyebutkan hisab dalam kaitannya keberadaan posisi Bulan dan Matahari. Adapun korelasi atau hubungan ayat al-Qur'an dengan konsep astronomi (hisab rukyat) berdasarkan tafsir dan asbabun nuzul menunjukkan keserasian dengan ilmu astronomi. Oleh karenanya, ilmu astronomi (ilmu falak) sangat dibutuhkan sebagai alat bantu untuk memahami ayat-ayat Allah di dalam al-Qur'an dan 
di alam semesta ini. Sehingga isyarat yang jelas dan lengkap tentang tata cara hisab-rukyat penentuan awal bulan di dalam al-Qur'an akan didapatkan Adapun untuk menjembatani antara pesan al-Qur'an dan as-Sunah (dalil syar'i), rukyat atau observasi, serta hisab diperlukan pemahaman yang komprehensif dengan paradigma objektif-ilmiah dalam memahami konsep hisab dan rukyat sebagai satu kesatuan yang tidak dapat dipisahkan.

Kata Kunci: Astronomi, Pengetahuan, Pengamatan, Bulan

\section{A. Pendahuluan}

Pada dasarnya astronomi (hisab rukyat) merupakan salah satu disiplin ilmu pengetahuan yang sangat besar sumbangsihnya bagi pelaksanaan tugas-tugas umat manusia, baik tugas keagamaan maupun kemasyarakatan. Ilmu hisab rukyat merupakan ilmu yang secara khusus mengkaji dan mencermati peredaran benda-benda langit, terutama peredaran Matahari, Bulan dan Bumi, maka manfaatnya adalah manusia dapat mengetahui perjalanan waktu, perhitungan hari, bulan dan tahun. ${ }^{1}$

Hisab dan rukyat adalah dua hal yang penting bagi umat Islam, sebab pelaksanaan ibadah dalam ajaran Islam sering banyak dikaitkan dengan kedua istilah tersebut. Terdapat empat hal yang masuk dalam diskursus hisab rukyat; Pertama, Penentuan awal bulan Kamariah, Kedua penentuan waktu-waktu shalat, Ketiga, menentukan bayang dan arah kiblat, dan terakhir menentukan kapan dan dimana terjadinya gerhana.

Dari keempat hal tersebut, yang paling banyak menimbulkan polemik di masyarakat adalah penentuan Awal bulan Kamariah. Karena Dalam penentuan waktu-waktu shalat, arah kiblat, dan gerhana, nampaknya tidak ada lagi yang mempersoalkan tentang kebolehan penggunaan hasil perhitungan hisab. Hal ini berbeda dengan penentuan awal bulan Kamariah yang masih menimbulkan perbedaan, terutama bulan-bulan yang didalamnya terdapat ritual yang sangat penting bagi umat Islam, seperti Puasa Ramadhan, Hari Idul Fitri (1 Syawal), Haji-wukuf arafah (Dzulhijjah). ${ }^{2}$

${ }^{1}$ Abd Salam Nawawi, Ilmu Falak: Cara Praktis Menghitung Waktu Shalat, Arah Kiblat dan Awal Bulan (Sidoarjo: Aqaba, 2010), 1.

${ }^{2}$ Ahmad Izzuddin, Fiqih Hisab Rukyah Menyatukan NU dan Muhammadiyah dalam Penentuan Awal Ramadan, Idul Fitri, dan Idul Adha (Jakarta: Erlangga, 2007), 5. 
Umat Islam sampai saat ini masih belum menemukan titik temu hisab-rukyat. Berbagai upaya telah dilakukan untuk meredakan polemik perbedaan dikalangan penganut hisab (mazhab hisab), dan mazhab rukyat. Namun problematika klasik nan aktual ini masih belum menemukan titik temu untuk terciptanya kesatuan hisab rukyat.

Menurut Susiknan Azhari berdasarkan penelitiannya menerangkan bahwa salah satu problematika hisab rukyat di Indonesia khususnya, yakni adanya banyak perbedaan dalam penentuan awal bulan. ${ }^{3}$ Salah satu perbedaan yang terjadi yang masih terus dikaji dan diteliti yakni perbedaan penafsiran ayat-ayat al-Quran dan Hadis yang menjadi pedoman atau sumber rujukan syar'i dalam menentukan kapan awal dan akhir bulan Kamariah. Selain itu juga perbedaan penentuan awal bulan Kamariah juga ditentukan ditentukan dari banyaknya ragam metode dan kriteria baru dalam penentuan awal bulan Hijriah yang dianggap lebih akurat dan memadai. Perkembangan tersebut dapat dilihat dari perkembangan hisab. Perhitungan secara hisab yang pada awal mulanya secara 'urfi dan hakiki, kini mulai berkembang ke metode hisab yang lebih kontemporer dan lebih akurat, seperti Metode Ephemeris, Jean Meeus, New Comb, Almanak Nautica dan yang lainnya.

Banyaknya ragam penafsiran, metode dan kriteria dalam penentuan awal bulan Kamariah ini kian menambah daftar masalah perbedaan dalam menetapkan awal bulan Hijriah. Oleh karenanya, dalam paper ini, penulis mencoba untuk memetakan penafsiran ayat-ayat al-Qur'an yang berkaitan dengan hisab rukyat, khususnya dalam penentuan awal bulan Kamariah. Bagaimana al-Qur' an berbicara mengenai hisab-rukyat secara intens dengan dari sudut pandang tafsir dan asbabun nuzulnya. Kemudian bagaimana tinjauan astronomis menelaah ayat-ayat tersebut, adakah korelasi ayat alQuran dengan konsep astronomi yang ada.

\section{B. Permasalahan Hisab Rukyat}

Pembahasan hisab rukyat terutama dalam persoalan penentuan awal Ramadhan, Syawal, dan Dzulhijjah merupakan persoalan yang paling menarik dikaji. Begitu juga tentang isu cara melihat hilal untuk penentuan awal bulan kamariah yang terkait dengan prosesi ibadah Islam telah lama menjadi kontroversi selama lebih dari empat puluh tahun di Indonesia.

\footnotetext{
${ }^{3}$ Susiknan Azhari, Hisab \& Rukyat Wacana Untuk Membangun Kebersamaan di Tengah Perbedaan (Cet. I; Yogyakarta: Pustaka Pelajar, 2007), 24.
} 
Telaah Ayat-Ayat Hisab Rukyat Perspektif Astronomi

Kontroversi ini terjadi khususnya bila menyangkut persyaratan dan metodologinya yaitu dengan cara melihat secara langsung (rukyat) atau melalui perhitungan astronomis dan matematik (hisab). ${ }^{4}$

Hisab secara etimologi berasal dari bahasa Arab al-Hisab yang berarti al-Adad wa al-Ihsa', bilangan atau hitungan/kalkulasi. ${ }^{5}$ Adapun secara terminologi istilah hisab sering dihubungkan dengan ilmu hitung (arithmatic), yaitu suatu ilmu pengetahuan yang membahas tentang seluk beluk perhitungan. ${ }^{6}$ Dalam literatur klasik, ilmu hisab disamakan dengan ilmu falak (astronomi), yaitu suatu ilmu yang mempelajari dan menghitung posisi benda-benda langit, Matahari, Bulan, bintang dan planet.

Posisi benda langit yang dimaksud di sini adalah lebih khusus kepada posisi Matahari dan Bulan dilihat dari pengamat di bumi. Hitungan posisi ini penting dalam kaitannya dengan syariah khususnya masalah ibadah misalnya: shalat fardu menggunakan posisi Matahari sebagai acuan waktunya, penentuan arah kiblat dengan menghitung posisi bayangan Matahari, penentuan awal bulan Kamariah dengan menentukan dan melihat hilal, serta mengetahui kapan terjadi gerhana dengan menghitung posisi Matahari dan Bulan.

Rukyat secara etimologi berasal dari bahasa Arab, yaitu dari kata ra'a yang berarti melihat dengan mata ${ }^{7}$ dan mengamati. ${ }^{8}$ Kata rukyat pada umumnya diartikan dengan menggunakan mata kepala. ${ }^{9}$ Dalam disiplin astronomi (ilmu falak), rukyat dikenal dengan istilah observasi. Adapun istilah rukyat al-hilal dalam konteks penentuan awal bulan kamariah adalah melihat hilal dengan mata telanjang atau dengan menggunakan alat yang dilakukan setiap akhir bulan atau tanggal 29 bulan kamariah pada saat Matahari terbenam. ${ }^{10}$

40.

${ }^{4}$ Ahmad Izzuddin, Fiqih Hisab Rukyah Menyatukan NU dan Muhammadiyah, 39-

${ }^{5}$ Ahmad Warson Munawwir, Al-Munawir: Kamus Arab Indonesia (Surabaya: Pustaka Progresif,1997), 228.

${ }^{6}$ Muh. Hadi Bashori, Penanggalan Islam: Peradaban Tanpa Penanggalan, Inikah Pilihan Kita?(Jakarta: Quanta, 2014), 83.

${ }^{7}$ Ma'luf Loewis, Al-Munjid fi al-Lughah (Beirut: Dar al-Masyriq, 1986), 243.

${ }^{8}$ Ahmad Warson Munawwir, Al-Munawir, 495.

${ }^{9}$ Susiknan Azhari, Ensiklopedi Hisab Rukyat (Yogyakarta: Pustaka Pelajar, 2005), 128.

${ }^{10}$ Muhyidin Khazin, Ilmu Falak dalam Teori dan Praktik (Yogyakarta: Buana Pustaka, 2008), 173. 


\section{Nursodik}

Selain itu, rukyat dikenal sebagai sistem penentuan awal bulan Kamariah terutama bulan Ramadhan, Syawal, dan Dzulhijjah, sejak masa Rasulullah saw. dan permulaan Islam. ${ }^{11}$ Pada masalah itu, dalam awal bulan kamariah untuk keperluan waktu-waktu ibadah ditentukan secara sederhana, yaitu dengan pengamatan hilal secara langsung tanpa menggunakan alat (rukyat bi al-fi'li). ${ }^{12}$

\section{Dalil Syar'i tentang Hisab Rukyat}

Banyak dalil-dalil nash, baik al-Quran maupun hadis yang berbicara tentang waktu, khususnya terrkait penentuan awal bulan kamariah. Dalam al-Qur'an terdapat penekanan arti penting pengorganisasian waktu secara keseluruhan yang harus dilakukan dengan cermat dan komprehensif, dan bilamana diabaikan akan mengakibatkan kurigian. Akan tetapi Allah swt. tidak hanya memperingatkan arti penting pengorganisasian waktu saja, melainkan memberi petunjuk pokok bagaimana pengorganisasian waktu melalui kalender itu dilakukan. Adapun lafal-lafal yang berakar dari kata hasaba yang berarti menghitung, menduga dan menganggap, dalam alQur'an terdapat 109 macam dengan bentuk yang bervariasi, mulai dari pertanggungjawaban, perhitungan dan menghisab.

Dalam Almanak Hisab Rukyat yang diterbitkan oleh Departemen Agama RI dijelaskan ada lima belas ayat Al-Qur'an dan sembilan hadis Nabi saw. yang terkait dengan penentuan awal bulan Kamariah (kalender Hijriah). ${ }^{13}$ Jules La Beame dalam kitabnya yang berjudul Le Koran Analyse yang diterjemahkan ke dalam bahasa Arab oleh Muhammad Fuad Abdul Baqi, $s$

\footnotetext{
${ }^{11}$ Ahmad Musonnif, Ilmu Falak (Yogyakarta: Teras, 2011), 133.

${ }^{12}$ Syamsul Anwar, Hari Raya \& Problematika Hisab-Rukyat (Yogyakarta: Suara Muhammadiyah, 2008), 117. Lihat pula A. Masroeri Ghozalie, Pedoman Rukyat dan Hisab Nadhlatul Ulama (Jakarta: LFPBNU, 2006), 2.

${ }^{13}$ Ayat-ayat yang dimaksud adalah QS al-Baqarah/2: 185, 189; QS Yunus/10: 5; QS Al-Isra'/17: 12, QS an-Nahl/16: 16; QS at-Taubah/9: 36; QS al-Hijr/15: 16; QS alAnbiya'/21: 33; QS al-An'am/6: 96-97; QS al-Rahman/55: 5; dan QS Yasin/36: 38-40. Uraian selengkapnya baca Departemen Agama RI, Almanak Hisab Rukyat (Cet. II; Jakarta: Proyek Pembinaan Badan Peradilan Agama, 1998/1999), 7-13.
} 
ebagaimana dikutip Susiknan Azhari, mengklasifikasi ayat-ayat al-Qur'an yang terkait dengan penentuan awal bulan Kamariah (kalender Hijriah) berjumlah lima ayat. ${ }^{14}$

Berdasarkan uraian di atas, Dalam al-Quran tidak ditemukan ayatayat yang menjelaskan secara implisit tentang penentuan awal bulan kamariah dengan menggunakan hisab, namun secara eksplisit ada beberapa ayat al-Qur' an yang menyebutkan hisab dalam kaitannya keberadaan posisi Bulan dan Matahari. Oleh karena itu, penulis akan menghubungkan ayatayat yang secara langsung membicarakan tentang hisab rukyat dan prinsipprinsipnya antara lain: QS Yunus/10: 5; QS al-Baqarah/2: 189 dan QS Yasin/36: 39-40 .

1. QS Yunus/10: 5:

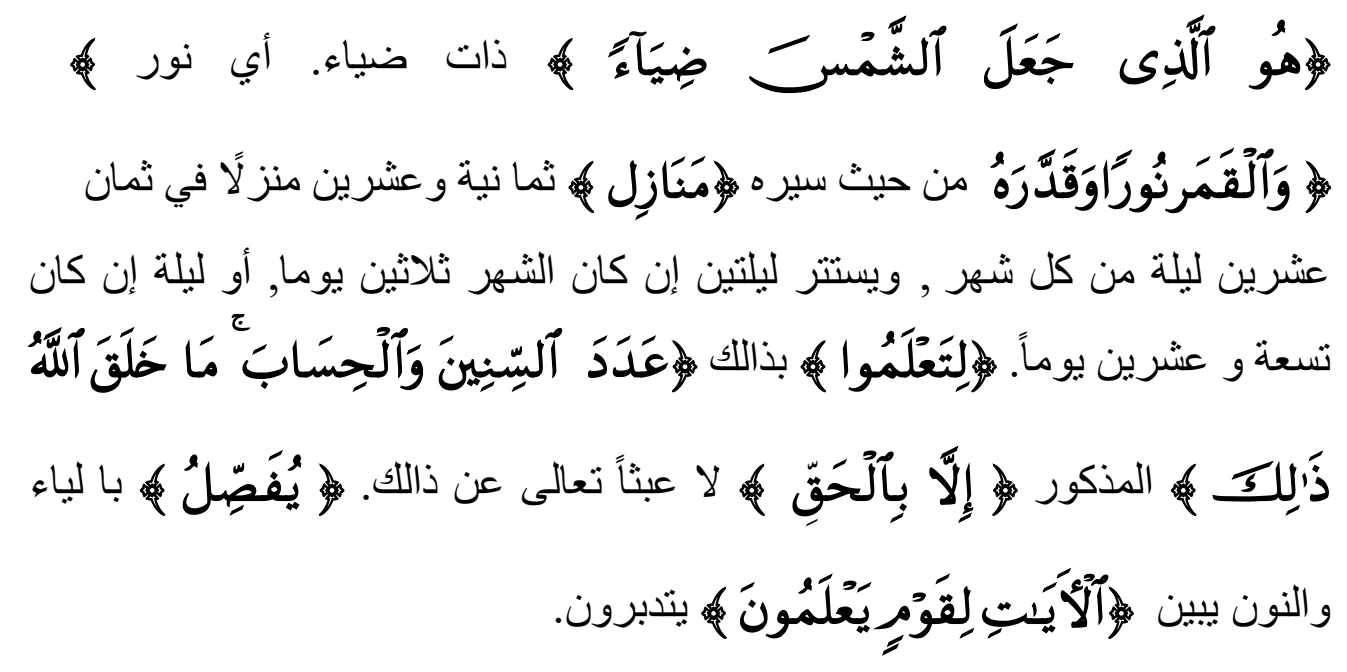

Terjemahnya:

(Dia-lah yang menjadikan Matahari bersinar) mempunyai sinar. (Dan Bulan bercahaya dan ditetapkan-Nya bagi Bulan) dalam perjalanannya (manzilah-manzilah) selama dua puluh depalan malam untuk setiap bulan, setiap malam daripada dua puluh delapan malam itu memperoleh suatu manzilah, kemudian tidak tampak selama dua malam, jika jumlah hari bulan yang bersangkutan ada tiga puluh hari. Atau tidak tampak selama satu malam, jika ternyata jumlah hari bulan

\footnotetext{
${ }^{14}$ Susiknan Azhari, Ilmu Falak, Perjumpaan Khazanah Islam dan Sains Modern
} (Yogyakarta: Suara Muhammadiyah, 2007), 85. 


\section{Nursodik}

yang bersangkutan ada dua puluh sembilan hari. (supaya kalian mengetahui) melalui hal tersebut. (bilangan tahun dan perhitungan waktu, Allah tidak menciptakan yang demikian itu) hal-hal yang telah disebutkan itu. (melainkan dengan hak ) bukannya main-main, Maha Suci Allah dari perbuatan tersebut (Dia menjelaskan) dapat dibaca "Yufashilu dan Nufashshilu", artinya Dia menerangkan atau Kami menerangkan, (tanda-tanda kepada orang-orang yang mengetahui) yakni orang-orang yang mau berpikir). ${ }^{15}$

Pada ayat tersebut Allah swt. memberi kabar tentang ciptaan-Nya berupa tanda-tanda yang menunjukkan atas kekuasaan dan keagungan kerajaan-Nya. Sesungguhnya Allah menjadikan cahaya yang memancar dari Matahari sebagai sinar dan menjadikan cahaya Bulan sebagai penerang. Yang ini merupakan cahaya Matahari dan yang itu adalah cahaya Bulan. ${ }^{16}$ Allah swt. menjadikan kekuasaan Matahari pada siang dan kekuasaan Bulan pada malam hari. Allah menetapkan manzilah-manzilah bagi Bulan yang artinya tempat-tempat dalam perjalanannya mengitari Matahari, sehingga Bulan terlihat berbeda di Bumi sesuai dengan posisinya dengan Matahari.

2. QS al-Baqarah/2: 189:

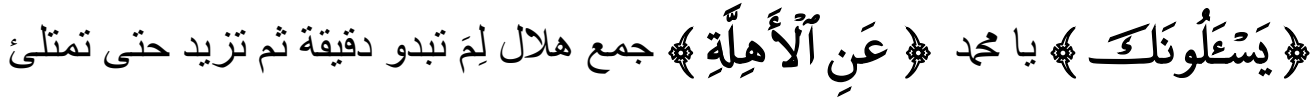

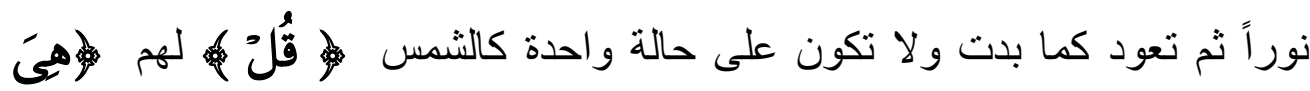

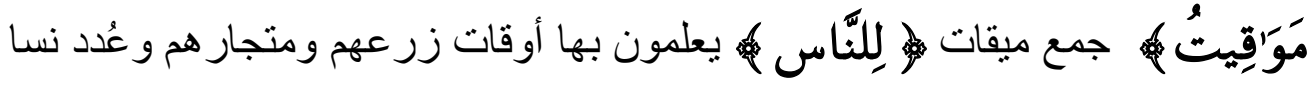

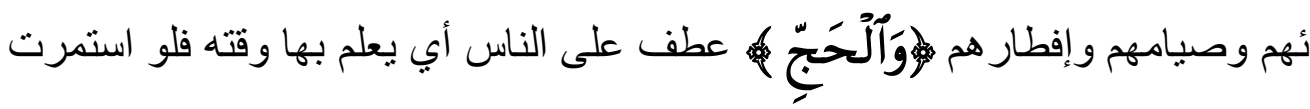

$$
\begin{aligned}
& \text { على حا لة لم يعرف ذللك }
\end{aligned}
$$

${ }^{15}$ Jalaluddin Abdurahman Abi Bakr al-Suyuthi dan Jalaluddin Muhammad bin Ahmad bin Muhammad Mahalli, Tafsir Imamain al-Jalalain (Bairut: Dar Ibnu Katsir, 1990), 850. Untuk selanjutnya disebut al-Suyuthi.

${ }^{16}$ Abi al-Fida' Ismail bin Umar bin Katsir al-Qursyi al-Dimasyqy (Beirut: Dar alThibah, 2003), 234. Selanjutnya disebut Ibn Katsir.

${ }^{17}$ M. Quraish Shihab, Tafsir al-Misbah, Juz 6 (Jakarta: Lentera Hati, 2004), 20. 
Terjemahnya:

(Mereka bertanya kepadamu) hai Muhammad, (tentang Bulan sabit). "Ahillah" jamak dari "hilal'. Pada permulaannya tampak kecil tipis kemudian terus bertambah hinggs penuh dengan cahaya. Lalu kembali sebagaimana semula, maka keadaannya tidak seperti Matahari yang tetap. (Katakanlah) kepada mereka, (Ia adalah tanda-tanda waktu); "mawaqit" jamak dari kata "miqat." (Bagi Manusia) untuk mengetahui waktu bercocok tanam, berdagang, iddah wanita, berpuasa, dan berbuka mereka. (Dan bagi Haji) diathafkan atau dihubungkan kepada manusia, maksudnya untuk diketahui waktunya. Karena seandainya Bulan tetap dalam keadaan yang sama, tentulah hal itu tidak dapat diketahui. ${ }^{18}$

Ayat ini dipahami bahwa al-ahillah (hilal) atau Bulan sabit itu sebagai referensi penentuan waktu secara umum dan manasik haji. Ayat ini turun dilatarbelakangi pertanyaan para sahabat tentang Bulan sabit, mengapa Bulan pada mulanya terlihat seperti sabit, kecil, tetapi dari malam ke malam membesar hingga mencapai purnama, kemudian mengecil lagi sampai menghilang dari pandangan? Maka turunlah ayat ini sebagai jawaban atas pertanyaan para sahabat tersebut. ${ }^{19}$

Sebenarnya ayat di atas mengindikasikan bahwa perubahan bentuk semu Bulan (fase-fase Bulan) merupakan pertanda bahwa perubahan waktu. Hal ini dapat dimengerti karena hilal merupakan salah satu bentuk semu Bulan di antara fase-fase yang dialaminya selama dalam peredaran mengelilingi Bumi, dan bersama-sama dengan Bumi mengelilingi Matahari. Penyebutan al-ahillah (hilal) dalam ayat tersebut bersifat umum, mutlak dan fleksibel, sehingga dapat diterjemahkan ke dalam beberapa pengertian. Secara astronomis, hilal bisa saja dinyatakan sebagai bentuk semu Bulan yang paling kecil menghadap ke Bumi, artinya permukaan Bulan yang terkena sinar Matahari yang menghadap ke Bumi dalam keadaan paling kecil, atau bisa juga diartikan penampakan Bulan pertama kali setelah mengalami ijtima' ${ }^{20}$

${ }^{18}$ Al-Suyuthi, Tafsir Imamain al-Jalalain, 202.

${ }^{19}$ M. Quraish Shihab, Tafsir al-Misbah, Juz 6, 417.

${ }^{20}$ M. Ma'rifat Iman, Kalender Pemersatu Dunia Islam (Jakarta: Gaung Persada Press, 2010), 117. 


\section{Nursodik}

3. QS Yasin/36: 39-40

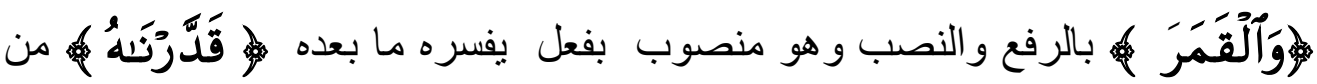

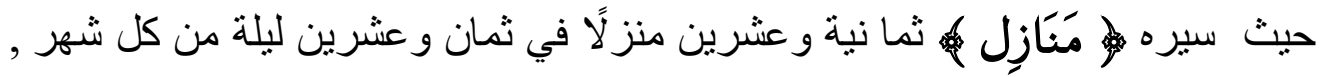

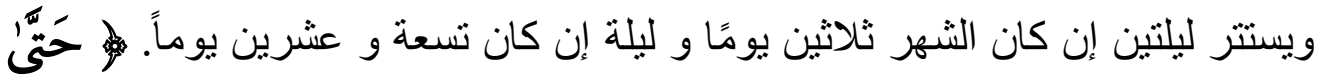

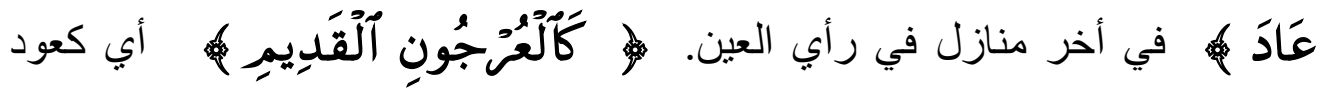
اشماريخ إذا عتق فإنه يرق ويتقوس ويصفر.

Terjemahnya:

(dan bagi Bulan) dapat dibaca rofa' atau nashab. Bila dibaca nashab berarti di nashabkan oleh fiil sesudahnya yang berfungsi menafsirkannya yaitu qaddarnahu (telah kami tetapkam) bagi peredarannya. (manzilah-manzilah), sebanyak dua puluh delapan manzilah selama dua puluh delapan malam untuk setiap bulannya. Kemudian bersembunyi selama dua malam, jika bilangan satu bulan tiga puluh hari, dan satu malam jika bilanganj satu bulan dua puluh sembilan hari (sehingga kembalilah ia ) setelah Dia sampai ke manzilah yang terakhir, menurut pandangan mata- (sebagai bentuk tandan yang tua) bila sudah lanjut masanya bagaikan ketandan, lalu menipis, berbentuk sabit dan berwarna kuning. ${ }^{21}$

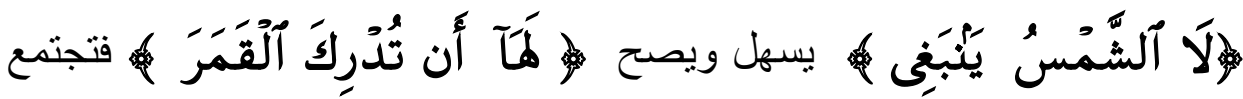

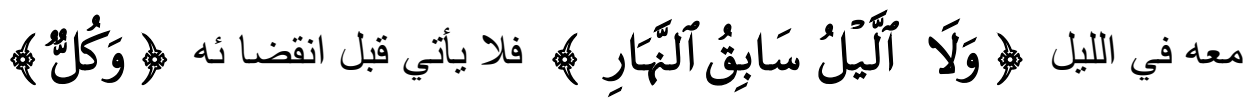

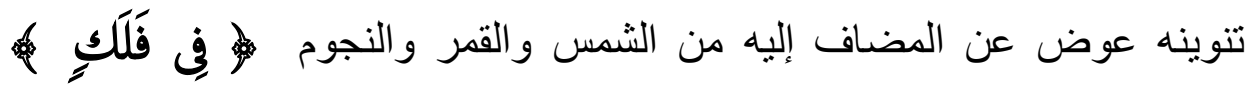

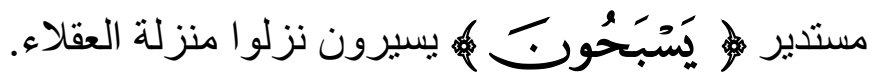

${ }^{21}$ Al-Suyuthi, Tafsir Imamain al-Jalalain, 582. 
Telaah Ayat-Ayat Hisab Rukyat Perspektif Astronomi

Terjemahnya:

(Tidaklah mungkin bagi Matahari) tidak akan terjadi (mendapatkan Bulan) yaitu Matahari dan Bulan bersatu di malam hari- (dan malam pun tidak dapat mendahului siang) malam hari tidak akan datang sebelum habis waktu siang hari- (dan masing-masing) Matahari, Bulan dan bintang-bintang. Tanwin lafaz "Kullun" ini merupakan pergantian dari mudhaf ilaih (pada garis edarnya ) yang membundar. (beredar ) pada garis edarnya masing-masing. Di dalam ungkapan ini benda-benda langit diserupakan sebagai makhluk yang berakal, karenanya mereka diungkapkan dengan lafaz "Yasbahuna."22

Mencermati ayat tersebut dapat dipahami bahwa satu siklus peredaran Bulan melalui fase-fasenya adalah mulai dari keadaan Bulan sebagai "bentuk tandan tua" ("urjun al-qadim), Maksudnya Bulan-bulan itu pada Awal bulan, kecil berbentuk sabit, kemudian sesudah menempati manzilah-manzilah, Dia menjadi purnama, kemudian pada manzilah terakhir kelihatan seperti tandan kering yang melengkung. Menurut Djambek, ayat di atas mengggambarkan bahwa bentuk Bulan yang terlihat di bumi setiap hari mengalami perubahan. Mula-mula kecil, membesar menjadi setengah lingkaran, purnama (setengah lingkaran penuh), kemudian mengecil kembali. Akhirnya menghilang dan muncul kembali berbentuk Bulan sabit. Periode perubahan bentuk Bulan tersebut adalah sebagai akibat pergerakan menelusuri manzilah satu ke manzilah lainnnya dan perubahan ini merupakan periode pergantian waktu bulan kamariah. Bentuk Bulan sabit adalah bentuk Bulan yang terjadi pada awal bulan Kamariah. ${ }^{23}$

Kemudian, Oman Fathurohman menyebutkan bahwa ayat diatas secara eksplisit menjelaskan bahwa bentuk-bentuk semu Bulan tersebut ditandai dengan dua unsur. Pertama, bagian permukaan Bulan yang tampak dari bumi disinari Matahari seperti yang dilukiskan dalam QS Yasin/36: 39. Kedua, kedudukan Bulan dan posisinya terhadap Matahari (mendahului Matahari) seperti yang tertuang dalam QS Yasin/36: $40 .^{24}$

${ }^{22}$ Al-Suyuthi, Tafsir Imamain al-Jalalain, 582.

${ }^{23}$ Saadoe'ddin Djambek, Hisab Awal Bulan (Jakarta: Tintamas, 1976), 10.

${ }^{24}$ Oman Fathurrahman, "Metode Penentuan Awal Bulan Kamariah," Makalah Disampaikan dalam Acara Sosialisasi Pandangan Muhammadiyah dalam Menentukan Awal Bulan Kamariah di Jakarta, 18 Agustus 2008, 19-24. 
Menurut Quraish Shihab dalam Tafsir al-Mishbah menerangkan bahwa Perjalanan bulan seperti yang dijelaskan ayat di atas juga menggambarkan juga perjalanan hidup banyak manusia dipentas bumi ini. Ia beranjak sedikit demi sedikit dari bayi, remaja, hingga dewasa, kemudian menurun kekuatannya, melengkung, dan membungkuk badannya hingga akhirnya menua dan mati. ${ }^{25}$

Ketika mencermati asbab al-nuzul-nya, para ulama menekankan pentingnya asbab al-nuzul tersebut untuk memahami makna ayat secara sahih, sebab sebagian ayat al-Qur'an tidak dapat dipahami maknanya dengan benar, kecuali dengan memahami asbab al-nuzul-nya. Al-Wahidi (w. $427 \mathrm{H}$ ) mengatakan "tidak mungkin mengetahui tafsir suatu ayat (dengan benar) kecuali dengan mengetahui kisahnya dan penjelasan asbabun nuzulnnya." Ibnu Taimiyyah (w. $726 \mathrm{H}$ ) berkata "mengetahui asbab al-nuzul akan membantu memahami suatu ayat, sebab ilmu tentang sebab akan menghasilkan tentang akibat (pemahaman ayat)." Ibnu Daqiqil 'Id (w. 702 H) menyatakan "mengetahui asbab al-nuzul adalah jalan yang kuat untuk memahami makna-makna al-Qur'an." ${ }^{26}$ Namun, ayat-ayat yang terdapat dalam al-Qur'an tidak semuanya mempunyai asbab al-nuzul.

Oleh karenanya, dalam tulisan ini akan dibahas ayat-ayat tentang hisab rukyat secara umum, yaitu QS Yunus/10: 5; QS Yasin/36: 39-40, dan QS al-Baqarah/2: 189. Dari ketiga ayat tersebut hanya surat al-Baqarah ayat 189 saja yang mempunyai asbabun nuzul. Selain itu, QS. Al-Baqarah:189 diturunkan sebagai jawaban terhadap banyaknya pertanyaan kepada Rasulullah saw. tentang peredaran bulan.

Sebagian diriwayatkan oleh Ibnu Abi Hatim dari al-'Aufi yang bersumber dari Ibnu Abbas. Menurut riwayat lain, orang-orang bertanya kepada Rasulullah saw.: "Untuk apa diciptakannya bulan sabit?" Maka turun ayat tersebut di atas (QS al-Baqarah/2: 189) sebagai penjelasan. ${ }^{27}$

Diriwayatkan oleh Ibnu Abi al-Hatim yang bersumber dari Aliyah. Menurut riwayat lain, Yas-alunaka 'anil ahillah... (Mereka bertanya tentang Bulan sabit...) sampai ...lin nasi wal hajj... (... bagi manusia dan [bagi ibadat] haji... ) (QS al-Baqarah/2: 189) ini berkenaan dengan pertanyaan

\footnotetext{
${ }^{25}$ M. Quraish Shihab, Tafsir al-Misbah, Juz 6, 417.

${ }^{26}$ Masjfuk Zuhdi, Pengantar Ulumul Quran (Cet. IV; Surabaya: Bina Ilmu, 1993),

${ }^{27}$ M. Quraish Shihab, Tafsir al-Misbah, Juz 6, 417.
} 46. 
Mu'adz bin Jabbal dan Tsa'labah bin Ghunamah kepada Rasulullah saw.: "Ya Rasulullah! Mengapa Bulan sabit itu mulai timbul kecil sehalus benang, kemudian bertambah besar hingga bundar dan kembali seperti semula, tiada tetap bentuknya?" Sebagai jawabannya turunlah ayat tersebut. ${ }^{28}$

\section{Analisis Tafsir Astronomi}

Diskusi soal hisab rukyat penentuan awal Ramadhan, Syawal, dan Dzulhijjah seringkali terfokus pada pemaknaan rukyat dan pengambilan dalil dari banyak hadis. Padahal seperti yang telah dijelaskan bahwa minim sekali pengambilan dalil dari al-Qur' an dalam hal operasionalisasi penentuan awal bulan tersebut, karena memang al-Qur'an tidak secara eksplisit mengungkapkan tata caranya seperti dalam hadis.

Jika sekedar mengkaji ilmu tafsir saja, yang selama ini digunakan oleh para ulama, kita sulit menemukan isyarat operasionalisasi penentuan awal bulan qamariyah di dalam al-Qur'an. Oleh karenanya dibutuhkan alat bantu astronomi untuk memahami ayat-ayat Allah swt. di dalam al-Qur'an dan di alam. Kita akan mendapatkan isyarat yang jelas dan lengkap tata cara penentuan awal bulan itu di dalam al-Qur'an. Memang bukan pada satu rangkaian ayat, tetapi dalam kaidah memahami al-Qur'an, satu ayat alQur'an bisa dijelaskan dengan ayat-ayat lainnya. ${ }^{29}$ Menurut T. Djamaluddin, dengan pemahaman astronomi yang baik, maka bisa menemukan isyarat yang runtut dan jelas soal penentuan awal bulan Kamariyah khususnya awal Ramadhan, Syawal, dan Dzulhjjah. Berikut ini ayat-ayat pokok yang menuntun menemukan isyarat itu yang dipandu pemahaman ayat-ayat kauniyah dengan astronomi atau yang disebut penulis dengan tafsir astronomi.

Revolusi mengelilingi bumi telah pula ditunjukkan melalui firman Allah swt. dalam QS al-Baqarah/2: 189. Menurut Saadoe'ddin Djambek, ayat di atas mengggambarkan bahwa bentuk Bulan yang terlihat di bumi setiap hari mengalami perubahan. Mula-mula kecil, membesar menjadi setengah lingkaran, purnama (setengah lingkaran penuh), kemudian mengecil kembali. Akhirnya menghilang dan muncul kembali berbentuk Bulan sabit. Periode perubahan bentuk Bulan tersebut adalah sebagai akibat pergerakan menelusuri manzilah satu ke manzilah lainnnya dan perubahan

\footnotetext{
${ }^{28}$ M. Quraish Shihab, Tafsir al-Misbah, Juz 6, 417.

${ }^{29}$ T. Djamaluddin, Semesta Pun Berthawaf(Bandung: Mizan Publishing, 2010 ), 2.
} 
ini merupakan periode pergantian waktu bulan kamariah. Bentuk Bulan sabit adalah bentuk Bulan yang terjadi pada awal bulan Kamariah. ${ }^{30}$

Selanjutnya, perubahan bentuk semu Bulan ditunjukkan oleh firman Allah swt. dalam QS Yunus/10: 5. Menurut ayat tersebut, Allah swt. telah menentukan manzilah-manzilah (fase-fase) bagi Bulan itu. Fase-fase Bulan tidak lain kecuali posisi-posisi Bulan pada saat tertentu terhadap Matahari dan Bumi. Fase-fase itu ditempati oleh Bulan setiap hari dalam peredarannya mengelilingi Bumi. ${ }^{31}$ Perubahan posisi Bulan terhadap Bumi dan Matahari menyebabkan adanya perubahan bentuk semu Bulan. Perubahan bentuk semu Bulan itu dapat dijadikan dasar untuk menentukan pengorganisasian waktu ke dalam satuan hari/tanggal, bulan, tahun, dan seterusnya. Perubahan posisi Bulan yang relatif konstan itu sekaligus dapat dipastikan perhitungannya. ${ }^{32}$

Kemudian, Oman Fathurohman menyebutkan bahwa QS Yunus/10: 5 secara eksplisit menjelaskan bahwa bentuk-bentuk semu Bulan tersebut ditandai dengan dua unsur. Pertama, bagian permukaan Bulan yang tampak dari bumi disinari Matahari seperti yang dilukiskan dalam surah Yasin ayat 39. Kedua, kedudukan Bulan dan posisinya terhadap Matahari (mendahului Matahari) seperti yang tertuang dalam QS Yasin/36: $40 .^{33}$

Pada QS Yasin/36: 39 memberi petunjuk tentang dimulainya bulan baru, yaitu bila ia telah kembali kepada bentuknya yang paling kecil. Dan bentuk yang paling kecil itu dicapainya di sekitar saat ijtimak. Menurut Sa'adoeddin Djambek, pada keadaan ijtimak, bulan hanya sekali-kali saja yang berkedudukan benar-benar dalam satu garis pandangan dengan Matahari, bila dilihat dari bumi. Hal ini dibuktikan secara ilmiah yaitu pada peristiwa gerhana Matahari, maka yang menghadap ke bumi adalah sematamata bagian bulan yang gelap. Biasanya pada saat ijtimak terdapat jarak diantara Bulan dan Matahari dapat mencapai $5^{\circ}$. Dalam keadaan yang yang demikian masih ada bagian permukaan Bulan yang diterangi Matahari, yang menghadap ke Bumi. Tetapi bagian itu tidak dapat dilihat juga karena Bulan

\footnotetext{
${ }^{30}$ Saadoe'ddin Djambek, Hisab Awal Bulan, 10.

${ }^{31}$ Oman Fathurrahman, "Metode Penentuan Awal Bulan Kamariah," 7.

${ }^{32}$ M. Ma'rifat Iman, Kalender Pemersatu Dunia Islam, 117.

${ }^{33}$ Oman Fathurrahman, "Metode Penentuan Awal Bulan Kamariah," 19-24.
} 
Telaah Ayat-Ayat Hisab Rukyat Perspektif Astronomi

yang sedang berijtimak itu letaknya terlalu dekat kepada Matahari, dan pada malam hari ia berada di bawah ufuk. ${ }^{34}$

Dalam hal ini amat menarik, bahwa saat ijtimak dicantumkan didalam almanak-almanak yang besar hanya sampai jumlah menitnya saja, padahal data-data yang lain dicatat sampai seperseribu detik. Sehubungan dengan itu dapat disimpulkan, bahwa saat Bulan "kembali kepada bentuk "urjunil qadim" sebagaimana ditunjukkan dalam ayat diatas susah sekali untuk menentukannya dengan tepat. Kemudian turunlah ayat selanjutnya sebagai petunjuk ayat sebelumnya, yaitu surat Yasin ayat 40. Ayat ini menjelaskan perjalanan bulanan Bulan dan perjalanan tahunan Matahari, yang arahnya sama-sama dari Barat ke Timur. Bulan menempuh setiap hari $13^{\circ}$ dan Matahari $1^{\circ}$, sehingga Bulanlah yang lebih cepat, dan tidak ada kemungkinan bagi Matahari mengejar, apalagi mendahuluinya.

Bila dihubungkan (munasabah) dengan QS Yasin/36: 39, maka bagian pertama ayat 40 ini menunjukkan lebih jelas bahwa Bulan baru ditandai dengan didahuluinya Matahari yang lamban oleh Bulan yang jauh lebih cepat jalannya. Bantuk-bentuk semu Bulan ditandai oleh dua unsur; Pertama, bagian permukaan Bulan yang tampak dari bumi disinari Matahari, Kedua, tempatnya di langit. Bulan baru kita lihat sebagai sabit tipis dan terbenam setelah Matahari terbenam. Bulan purnama kelihatan penuh dan terbit di waktu Matahari terbenam. Bulan tua kelihatan seperti sabit lagi, tetapi terbit pada dini hari mendahului Matahari.

Dalam ayat 39 dilukiskan pengaruh penyinaran Matahari terhadap Bulan baru ('urjunil qadim); pada bagian pertama ayat 40 dijelaskan kedudukannya (mendahului Matahari). Dengan jalan demikian dua unsur mengenai sifat-sifat Bulan baru itu dalam ayat-ayat diatas telah diterangkan dengan sempurna secara ilmu Astronomi.

Hal ini menunjukkan antara Bulan yang satu dengan yang lainnya tidak dapat dipisahkan dalam struktur penentuan awal bulan Kamariah, atau dalam hal ini (kalender Islam). Pertanyaaan yang dapat dimunculkan kenapa umat Islam terpaku pada bulan Ramadhan dan Syawal? Jawabnya karena pada bulan-bulan tersebut diperintahkan Rasulullah saw. untuk melakukan "observasi". Tentu saja jawaban ini tidak salah karena banyak matan hadis secara tekstual menginformasikan hal demikian. Lalu bagaimana jika dikaitkan dengan ayat-ayat al-Qur'an yang membicarakan tentang prinsip-

\footnotetext{
${ }^{34}$ Saadoe'ddin Djambek, Hisab Awal Bulan, 10.
} 
prinsip kalender diatas? Disinilah diperlukan kajian yang integratifinterkonektif. Selama persoalan hisab-rukyat dipahami secara terpisah dengan prinsip-prinsip penentuan awal bulan atau kalender Islam, maka selama itu pula perdebatan hisab dan rukyat tak kunjung selesai dan perbedaan dalam menentukan awal Ramadhan, Syawal, dan Zulhijjah akan terus berlangsung. ${ }^{35}$

Memang harus disadari dalam realitasnya hingga kini perdebatan hisab-rukyat sebagai metode untuk mengetahui hilal belum selesai baik tingkat nasional maupun internasional. Hal ini dapat dilihat hasil keputusan Konferensi Libanon 2010 dan Muktamar Mekah Februari 2012 yang lalu. Pada konferensi Libanon menyepakati penggunaan hisab untuk menentukan awal bulan Kamariah dan perlunya "Greenwich Islamy". Sementara itu pada Muktamar Mekah menekankan pentingnya observasi untuk menentukan awal bulan Kamariah. Dalam konteks Indonesiapun juga demikian adanya. Inilah kondisi objektif umat Islam yang perlu dipahami bersama. Untuk mengintegrasi diperlukan jihad bersama dengan penuh kearifan melalui kerja yang terarah dan sistematis. ${ }^{36}$

Dalam pandangan penulis mengenai penentuan awal bulan Kamariah memang sering terjadi perselisihan cara/metode yang dipakai. Satu pihak ada yang mengharuskan dengan rukyat saja dan pihak lain menghendaki hisab saja. Masing-masing mengemukakan argumentasi dan dalil-dalilnya sendiri, baik al-Qur'an maupun hadis. Oleh karena itu, perlu untuk menjembatani antara pesan al-Quran dan as-Sunah (Dalil Syar'i), rukyat atau "observasi", serta hisab. Dalam hal ini dua konsep pengertian "observasi; Pertama, "observasi" sebagai sumber data dan Kedua, "observasi" sebagai metode untuk menentukan awal bulan Kamariah. Demikian juga hisab memiliki dua pengertian; Pertama, hisab sebagai sumber data untuk menghitung ketinggian hilal dalam penentuan awal bulan Kamariah, Kedua hisab statusnya masih sebatas hipotesis verifikatif yang masih memerlukan pembuktian (observasi atau rukyat), sehingga kontinuitas rukyat yang dibuktikan dengan hasil hisab harus selalu dilakukan setiap akhir bulan Kamariah, tidak terbatas pada rukyat akhir bulan Sya'ban, Ramadhan dan Dzulqa'dah saja. Dalam kasus ini penulis mengusulkan perlunya "sertifikasi tempat rukyat (pos observasi) yang standar" agar dapat dijadikan tempat menggali data sebagaimana dilakukan

\footnotetext{
${ }^{35}$ Susiknan Azhari,, Hisab \& Rukyat Wacana Untuk Membangun Kebersamaan, 3.

${ }^{36}$ Susiknan Azhari,, Hisab \& Rukyat Wacana Untuk Membangun Kebersamaan, 3.
} 
Mohammad Ilyas dan dilakukan secara bersama-sama, berkesinambungan, dan melibatkan berbagai pihak. Pada akhirnya ketinggian hilal yang dapat dihasilkan obyektif-ilmiah, dan juga empiris-ilmiah sebagai hasil kompromi metode hisab dan rukyat.Hemat penulis, kegiatan ini penting untuk menarik titik temu, saling memahami, dan merubah paradigma yang terjadi saat ini agar ketegangan antara para pemeluk mazhab hisab dan rukyat dapat diakhiri.

\section{E. Penutup}

Setelah mempelajari dan membahas ayat-ayat al-Quran yang berkenaan dengan hisab rukyat penetapan awal bulan Kamariah dapat disimpulkan dalam al-Quran memang tidak ditemukan ayat-ayat yang menjelaskan secara implisit tentang penentuan awal bulan kamariah dengan menggunakan hisab, namun secara eksplisit ada beberapa ayat al-Qur'an yang menyebutkan hisab dalam kaitannya keberadaan posisi Bulan dan Matahari. Adapun korelasi atau hubungan ayat al-Qur'an dengan konsep astronomi (hisab rukyat) berdasarkan tafsir dan asbabun nuzul menunjukka keserasian dengan ilmu astronomi, seperti revolusi mengelilingi Bumi, perubahan bentuk semu Bulan, fase-fase Bulan dan teori atau prinsip-prinsip lainnya yang tersirat dalam QS Yunus/10: 5; QS al-Baqarah/2: 189; dan QS Yasin/36: 39-40.

Selain itu, ilmu astronomi (ilmu Falak) sangat dibutuhkan sebagai alat bantu, yang dalam hal ini untuk memahami ayat-ayat Allah di dalam alQur'an dan di alam semesta ini. Dengan bantuan ilmu astronomi ini kita akan mendapatkan isyarat yang jelas dan lengkap tentang tata cara hisabrukyat penentuan awal bulan di dalam al-Qur'an. Karena yang telah dijelaskan diatas bahwa minim sekali pengambilan dalil dari al-Qur'an dalam hal operasionalisasi penentuan awal bulan tersebut, karena memang al-Qur'an tidak secara eksplisit mengungkapkan tata caranya seperti dalam hadits. Adapun untuk menjembatani menjembatani antara pesan al-Quran dan as-Sunah (dalil Syar'i), rukyat atau "observasi", serta hisab diperlukan pemahaman yang komprehensif dengan paradigma objektif-ilmiah dalam memahami konsep hisab dan rukyat tersebut. 


\section{Daftar Pustaka}

Anwar, Syamsul Hari Raya \& Problematika Hisab-Rukyat. Yogyakarta: Suara Muhammadiyah, 2008.

Azhari, Susiknan. Ensiklopedi Hisab Rukyat. Yogyakarta: Pustaka Pelajar, 2005.

- Hisab \& Rukyat Wacana Untuk Membangun Kebersamaan di Tengah Perbedaan. Cet. I; Yogyakarta: Pustaka Pelajar, 2007.

. Ilmu Falak, Perjumpaan Khazanah Islam dan Sains Modern. Yogyakarta: Suara Muhammadiyah, 2007.

Bashori, Muh. Hadi. Penanggalan Islam: Peradaban Tanpa Penanggalan, Inikah Pilihan Kita? Jakarta: Quanta, 2014.

Departemen Agama RI. Almanak Hisab Rukyat. Cet. II; Jakarta: Proyek Pembinaan Badan Peradilan Agama, 1998/1999.

Al-Dimasyqy Abi al-Fida' Ismail bin Umar bin Katsir al-Qursyi. Beirut: Dar al-Thibah, 2003.

Djamaluddin, T. Semesta Pun Berthawaf. Bandung: Mizan Publishing, 2010.

Djambek, Saadoe'ddin. Hisab Awal Bulan. Jakarta: Tintamas, 1976.

Fathurrahman, Oman. "Metode Penentuan Awal Bulan Kamariah," Makalah Disampaikan dalam Acara Sosialisasi Pandangan Muhammadiyah dalam Menentukan Awal Bulan Kamariah di Jakarta, 18 Agustus 2008 .

Ghozalie, A. Masroeri. Pedoman Rukyat dan Hisab Nadhlatul Ulama. Jakarta: LFPBNU, 2006.

Iman, M. Ma'rifat. Kalender Pemersatu Dunia Islam. Jakarta: Gaung Persada Press, 2010.

Izzuddin, Ahmad. Fiqih Hisab Rukyah Menyatukan NU dan Muhammadiyah dalam Penentuan Awal Ramadan, Idul Fitri, dan Idul Adha. Jakarta: Erlangga, 2007.

Khazin, Muhyidin. Ilmu Falak dalam Teori dan Praktik. Yogyakarta: Buana Pustaka, 2008.

Loewis, Ma'luf. Al-Munjid fi al-Lughah. Beirut: Dar al-Masyriq, 1986. 
Telaah Ayat-Ayat Hisab Rukyat Perspektif Astronomi

Munawwir, Ahmad Warson. Al-Munawir: Kamus Arab Indonesia. Surabaya: Pustaka Progresif,1997.

Musonnif, Ahmad. Ilmu Falak. Yogyakarta: Teras, 2011.

Al-Nawawi, Abd Salam. Ilmu Falak: Cara Praktis Menghitung Waktu Shalat, Arah Kiblat dan Awal Bulan. Sidoarjo: Aqaba, 2010.

Shihab, M. Quraish. Tafsir al-Misbah, Juz 6. Jakarta: Lentera Hati, 2004.

Al-Suyuthi, Jalaluddin Abdurahman Abi Bakr, dan Jalaluddin Muhammad bin Ahmad bin Muhammad Mahalli, Tafsir Imamain al-Jalalain. Bairut: Dar Ibnu Katsir, 1990.

Zuhdi, Masjfuk. Pengantar Ulumul Quran. Cet. IV; Surabaya: Bina Ilmu, 1993. 